\title{
THEORETICAL ANALYSIS OF SOCIAL GENDER STEREOTYPES OF MODERN UKRAINIAN SOCIETY
}

\section{ТЕОРЕТИЧНИЙ АНАЛІЗ СОЦІАЛЬНИХ ҐЕНДЕРНИХ СТЕРЕОТИПІВ СУЧАСНОГО УКРАЇНСЬКОГО СУСПІЛЬСТВА}

\begin{abstract}
The article is devoted to the study and analysis of social gender stereotypes, research on the problem of understanding gender identification, norms of gender behavior. Theoretical aspects of the problem of gender and gender stereotypes in modern Ukrainian society are considered. The essence of the scientific concept "gender", "gender stereotypes", "social stereotypes" is revealed. Peculiarities and structure of gender stereotypes in various spheres of modern society are determined. The influence of social gender stereotypes on the individual way of life is determined; draw conclusions. It is concluded that gender social stereotypes still prevail in our society. We are expected to protect and provide for the family from men, and from women to expect motherhood, raising children and caring for the family and family comfort, but now also self-realization and work for themselves. It is determined that social gender stereotypes lead to simplification and distortion of the social environment, limit a person's behavior to a number of gender roles and expectations. The study concludes that in modern Ukrainian society there are many conflicting gender stereotypes and expectations of women and men, which can lead to conflicts and misunderstandings between members of different sexes, as well as inequality of different sexes in the system of social roles and social system. stratification. It is determined that public opinion records a fairly clear division of powers of women and men in Ukrainian society, which is manifested in the fact that men have more power in the spheres of work and socio-political life, and women - in the field of family relations. It is concluded that in modern Ukrainian society, despite the proclamation at the legislative level of the implementation of the principles of gender equality, there are stereotypes that form gender-role expectations, which, in turn, hinder its achievement.

Key words: gender, social gender stereotypes, gender policy, public opinion, social roles.
\end{abstract}

Стаття присвячена вивченню й аналізу соціальних ґендерних стереотипів, дослідженню проблеми розуміння ґендерної ідентифрікації, нормативів ґендерної поведінки. Розглянуто теоретичні аспекти проблеми ґендеру та ґендерних стереотипів у сучасному українському суспільстві. Розкрито суть наукових понять «ґендер», «ґендерні стереотипи», «соціальні стереотипи». Визначено особливості та структуру ґендерних стереотипів у різних сфрерах сучасного суспільства. Визначено вплив соціальних ґендерних стереотипів на індивідуальний життєвий шлях. Зроблено висновок, що ґендерні соціальні стереотипи досі панують у нашому суспільстві. Від чоловіків у нас чекають захисту $і$ забезпечення сімті, а від жінок материнства, виховування дітей і турботи про сім'ю сімейний затишок, але зараз ще й самореалізації та роботи для себе. Визначено, що соціальні ґендерні стереотипи призводять до спрощення та викривлення соціального середовища, обмежують поведінку особи низкою ґендерних ролей та очікувань. За результатами дослідження можна зробити висновок, що в сучасному українському суспільстві є багато суперечливих ґендерних стереотипів і очікувань у жінок і чоловіків, які можуть призводити до консрліктів і непорозуміння між представниками різних статей, а також до нерівності представників різних статей у системі соціальних ролей і системі соціальної стратифрікації. Визначено, що громадська думка фріксує досить чіткий розподіл владних повноважень жінок і чоловіків в українському суспільстві, який виявляється в тому, що чоловіки мають більше владних повноважень у сорерах роботи і соціально-політичного життя, а жінки - у ссрері сімейних відносин. Зроблено висновок, що в сучасному українському суспільстві, попри проголошення на законодавчому рівні впровадження принципів ґендерної рівності, поширені стереотипи, що формують статево-рольові очікування, які, своєю чергою, заважають досягненню зазначеної рівності.

Ключові слова: ґендер, сочіальні ґендерні стереотипи, ґендерна політика, громадська думка, соціальні ролі. University

Setting of the scientific problem. Gender equality is one of the principles of human rights, the basis of democratic development of states and the world community. The processes of globalization and integration are accompanied by the empowerment of women and men, overcoming the manifestations of occupational discrimination, gender segregation of labor, unequal pay, gender-based violence, and so on. They do not bypass the sphere of public service, education and science, the security and defense sector, etc. Gender inequality is a tangible manifestation of social differentiation of the population, which results in different opportunities for self-realization of women and men in society. It is not only about the equality of legal rights of women and men, but also the equality of conditions and opportunities for the exercise of these rights. Views on the role of men and women in society are formed in the process of socialization of the individual under the influence of family, school, media, social environment, as well as political and governmental structures. In the period of social transformations, the problem of gender identification is becoming increasingly important. Changing traditional ideas and stereotypes should be to rethink the established roles of man and woman, the realization that there are no purely masculine and feminine characteristics. All individuals have strength and weakness, independence and dependence, activity and passivity depending on certain conditions and situations. 
The relevance of the study lies in the weak study of gender stereotypes of Ukrainian modern society. The current stage of development of Ukrainian society is characterized by a kind of conflict between the traditional distribution of gender roles and patriarchal values (where areas of activity, social and family roles are traditionally marked as male and female and, respectively, as dominant and subordinate), on the one hand, and new, egalitarian challenges (promoting equality and interchangeability in different areas of activity of men and women as equal individuals) - on the other.

Analysis of the latest research and publications. L. Karamushka, O. Bondarchuk, T. Govorun, O. Goroshko, T. Govorun, O. Kis, V. Kravets, L. Danylenko and V. Oliynyk studied the problem of gender and gender stereotypes in their scientific works. In the 60's of the twentieth century in the Soviet Union began to study stereotypes, namely I. Kon, G. Kondratenko, V. Yadov, V. Ageev, G. Soldatova, N. Rozhdestvenskaya, T. Stefanenko. Unlike their Western counterparts, Soviet scholars sought stereotypes not only for the negative but also for the positive. In Ukrainian sociology, V. Arbenina, A. Ruchka, V. Sereda, and N. Yakovenko studied stereotypes. A. Ruchka considered stereotypes from the socio-cultural approach, studying their construction in a modern multicultural environment.

Defenition of research objectives. Our study is devoted to determining the current state of the spread of gender stereotypes of the Ukrainian population, as well as the attitude of people to gender issues at the present stage of development of public relations. To achieve this goal, the following scientific objectives were identified: to consider the theoretical aspects of gender, to consider gender research as an interdisciplinary scientific field; toanalyzethe peculiarities of theformation of gender stereotypes in Ukrainian society.

Presentation of the main research material. The term "stereotype" was first introduced into science in the 1920's in the United States, when there was a need to study the laws of mass consciousness. The concept of stereotype was introduced by the American essayist, political commentator, author of the concept of public opinion W. Lippman in his work "Public Opinion", which was devoted to the study of racial issues. When considering the concept of "social stereotype", we understand it as a schematic, standardized image or representation of social objects, usually emotionally colored and highly resilient. We can say that the "social stereotype" is a simplified, generalized perception of a person, group, social phenomenon or event. However, the stereotype may not be related to the experience of interaction with a given person, group, social phenomenon or event [2]. Stereotypes are an integral part of popular culture. It is through the use of certain stereotypes that such phenomena as sexism, racism, etc. have emerged.

In the psychological approach we can distinguish individualistic (T. Adorno, M. Horkheimer) and actually social (K. Jung, E. Fromm, S. Moskovichi) theory. Within the framework of socio-psychological theories, the concept of S. Moskovichi and K. Jung should be singled out. The main postulate of this social theory of stereotype is the position of social genesis, in a broad sense, is seen as the moment of origin and development of the stereotype. Stereotypes are created by a collective subject. The study of stereotype through the social aspect is one of the areas in the study of mass consciousness [4]. It was from the 1920's to the 1960's that stereotypes were viewed only on the negative side. V. Arbenina studied interethnic relations in the form of real interaction, which largely depends on the attitude to groups, which has developed in the mass and individual consciousness [6, p. 41]. At the heart of these ideas are stereotypes. V. Sereda considered stereotypes as an important component of national identity.

In general, the study of stereotypes can be divided into three areas devoted to various aspects of this social phenomenon, namely: 1) the study of the cognitive aspect of stereotypes (ie stereotypes formed during education, training, observation and reflection on the world); 2) the study of the affective aspect of stereotypes (ie stereotypes that arise under the influence of friendly or unfriendly); 3) the study of the social aspect of stereotypes (namely, stereotypes formed by the influence of various social interactions). It should be noted that regardless of the types of stereotypes, they perform important functions [6, p. 42]. According to W. Lippmann, stereotypes perform several important functions in human life, namely: reducing effort and time to analyze and understand a situation; protection of human status in society [2]. Thus, the genesis of the study of social stereotypes was reflected in sociological and psychological theories, which focused on the study of their essence, types and functions. Sociological theory of stereotypes developed in the twentieth century and its development is gaining only in applied research in certain areas.

Consider gender stereotypes as one of the types of social stereotypes In order to distinguish the concept of gender in sociology, ie in the context of social relations and processes, it is customary to use the concept of "gender" society. Gender is a social article. Gender is a system of values, norms and characteristics of male and female behavior, lifestyle, roles and relationships of women and men, acquired by them and supported by social institutions, acquired by them as individuals in the process of socialization determined by social, political, economic and cultural contexts of social life [7]. 
Gender as a social phenomenon is manifested on two levels: societal and individual. According to the theory of the Australian scientist R. Connell, gender is a structure of social relations, the core of which is the human reproductive sphere, and many practices that govern this structure, which bring reproductive differences between bodies in social processes. Against the background of the existence of such gender ideals as femininity and masculinity, gender stereotypes emerge. Gender stereotypes are widespread in society ideas about the characteristics and behavior of men and women. Gender stereotypes are related to the existing gender roles in a given society and serve to support and reproduce them. In particular, gender stereotypes support gender inequality [7]. Gender stereotypes as a social phenomenon have an uneven transformation over time and have a spatial dimension. According to the results of various surveys, the most common stereotypes about the behavioral characteristics of men and women are identified:

- male traits: independence, individualism, goal orientation, innovation, rationality, indifference, restraint, dominance, activity, courage, realism, risk-taking, aggression, rudeness, low anxiety;

- female traits: attachment, collectivism, relationship orientation, traditionalism, impulsiveness, emotionality, accuracy, flexibility, passivity, democracy, softness, tenderness, dreaminess, high anxiety.

Public opinion polls on gender stereotypes and gender issues confirm the existence of gender inequality in Ukrainian society, which consists in the disproportionate representation of both sexes in different spheres of life, different wages of women and men, the existence of persistent gender stereotypes with bright patriarchal coloring and expression. gender, etc. All this significantly limits both the access of members of the same sex to material resources, and their ability to fully realize themselves in various spheres of public life. Men continue to hold disproportionate numbers of senior government and administrative positions, earning higher salaries, citing the absence of discriminatory harassment of women. Due to the widespread stereotype of "politics is not a woman's business", it is much more difficult for women than for men to become deputies or hold responsible leadership positions [3]. And while women are more likely than men to find it difficult to take on leadership positions, men say career advancement is gender-independent. Public opinion records a fairly clear division of powers of women and men in Ukrainian society, which is manifested in the fact that men have more power in the spheres of work and socio-political life, and women - in the field of family relations. Only a third of the Ukrainian population tends to claim that power is evenly distributed between men and women in vari- ous spheres of public life, but this view is much more prevalent among men than among women. The higher the level of management, the greater the proportion of the population who prefer a man to a woman.

Thus, $47 \%$ tend to see "only a man" as President of Ukraine; The Prime Minister of Ukraine - 42\%; Chairman of the Verkhovna Rada of Ukraine $-44 \%$ of citizens. Accordingly, the share of those who tend to see women in these positions is $19 \%$. As the "political influence" of the position decreases, the share of citizens who consider it possible to entrust the position to representatives of both sexes increases [3]. The majority of Ukraine's population also believes that men have greater access to public funds and property than women. Moreover, the higher the level of education of citizens, the more they are convinced of the imbalance in access of women and men to material resources, the greater among them the share of those who believe that most of the material values are owned by men. At the same time, with regard to access to the family budget, most citizens claim that there is no discrimination here. Today, public opinion continues to reproduce the worst stereotypes of gender perception of managerial functions in society, when traditional spheres of life - family, culture, health care, etc. should be left only to women, and the rest, sometimes more technologically complex areas (economics, entrepreneurship, politics, etc.). ), can be successfully practiced only by men [3]. The declared thesis "there is no difference" in who will lead this or that branch of production, has in fact discriminatory its introduction in practice as in most cases in key leading positions the population prefers to see men. Although there are gender differences in barriers to the career development of women and men, there are other reasons that do not depend on gender, including a lack of professionalism in a particular field. According to the study, men more than women lack a sufficient level of education and professionalism (experience and knowledge). In contrast, women are hampered by family responsibilities (maternity leave, family and children). Also, women more often than men suffer from the bias of the leadership to nominate them to leadership positions [3].

On the other hand, researchers cover the issues of gender perception of political parties, noting the dominant indifference of the population to the sex of a political leader, the ratio of women and men in the lists of political associations, and public activities of parties to establish gender parity in Ukraine. In addition, there is no mass support for the decision to achieve gender parity in the legislature by artificially determining the proportions of men and women in political parties. Among those who are interested in the gender balance of political parties, the major- 
ity are experienced and educated people. However, in general, for the majority of the population, the presence of women on the lists of political parties is not a decisive factor in supporting them.

The results of scientific research show that Ukrainian society is still far from egalitarian, which especially affects the spheres of social, labor and family relations. The vast majority of respondents still define a man as the head of the family, who should fully provide for the family. At the same time, they are recognized as the best leaders, most of whom have the following qualities: professionalism, political culture, but, in turn, also careerism, brutality and arrogance, imitation of work.

In the distribution of roles in the family, the man is defined as the one who prefers to perform the function of material support and leadership in the family, and it is believed that he and the woman should participate in raising children, maintaining a family home, working in the household. But with such a fairly ideal picture, there are some nuances: a man as a caregiver is recognized as a minority of the population compared to a woman and the option when both parents are engaged in this case (this case is defined as the most acceptable), according to this population is divided almost equally who advocate the distribution of childcare leave between a man and a woman and those who deny it. But in reality, a meager number of men take such a vacation.

Another difference between the role of men in the division of family responsibilities is that they actually spend much less time on household chores, and therefore, household chores fall on the shoulders of women. Of course, few people deny a woman's right to realize herself in the public sphere, but there is no promotion of her work. In particular, under conditions of going to work, a woman bears a double (work - home), and sometimes triple (work - home - children) load. Most women work two shifts a day (at work and at home). But for most, this is a necessity due to the need to provide for the family, which is the main motive for early (before the child is 3 years old) women to work, as well as a strong argument when considering the birth of (another) child. However, going to work does not always significantly improve the living conditions of women and their families, as they work in lower paid positions than men. The reason for this is that respondents identify employment in those economic areas that are less paid [2].

In this social order, citizens are ambivalent about the introduction of equal childcare leave for both parents, which would be logical given that, according to respondents, a woman is less able to provide for the family, so in general this task is entrusted to the husband. Thus, in modern Ukrainian society, despite the proclaimed gender equality, there are stereotypes that form gender-role expectations, which, in turn, hinder its emergence. In particular, they prevent equal access for men and women to leadership positions - a woman is considered a better performer than a leader, men - on the contrary. This can be recorded due to the presence in the minds of more than $50 \%$ of citizens of the division of professions into male and female. The first, as a rule, are connected with physical work, work with various mechanical devices, driving; the latter are more in line with services in the education, medicine and beauty industries [2]. The attitude towards women engaged in entrepreneurial activity, especially big business, is not very favorable, which, of course, has a negative impact on the entrepreneurial activity of the majority of the population of Ukraine, which, in turn, has a negative impact on economic development. In general, the tendency, although implicit, is that a woman is still given a place for self-realization in the family, in particular in the birth of children, their upbringing, in general in the household [1].

Thus, we can say that in modern Ukrainian society there are gender stereotypes in the field of social and labor relations and their impact on the distribution of roles in the family is significant. In addition, it should be remembered that gender stereotypes of Ukrainian society belong to the phenomena of cultural order and were formed under the influence of specific historical, political and socio-economic conditions. Having a social nature, gender stereotype acts as a result of socio-cultural norms and expectations, performing a number of social functions. And in the performance of these functions reflects the determined dependence between men and women of different social status, different age and educational level, different regions of residence and even different types of settlements. As a result of many such interactions, the gender picture of modern Ukrainian society cannot be defined as completely homogeneous and clearly structured, as it is sometimes characterized by polar gender stereotypes inherent in residents of certain regions or different social groups.

Conclusions. Thus, we investigated the peculiarities of the formation of gender stereotypes in the Internet space and the factors that influence them. In this regard, we can focus on the following gender stereotypes: for men - the attitude to the stronger sex, the ability to protect, the material support of the family, the consumption of female sexuality; for women - motherhood, sexual object, own high sexuality, aestheticization of female appearance, gradation by age, hair color, internal features. It is important to note the interest of women in professional activities. Public opinion polls on gender stereotypes and gender issues confirm the prevalence of gender inequality in Ukrainian society, which 
is the disproportionate representation of both sexes in different spheres of life, different wages of women and men, the existence of persistent gender stereotypes with bright patriarchal colors. by gender, etc. All this significantly limits both the access of members of the same sex to material resources, and their ability to fully realize themselves in various spheres of public life. Men continue to hold the vast majority of senior government and administrative positions, receiving higher salaries, citing the lack of discriminatory harassment of women. Public opinion records a fairly clear division of powers of women and men in Ukrainian society, which is manifested in the fact that men have more power in the spheres of work and socio-political life, and women - in the field of family relations. Only a third of the Ukrainian population tends to claim that power is evenly distributed between men and women in various spheres of public life, but this view is much more prevalent among men than among women. The higher the level of management, the greater the proportion of the population who prefer a man to a woman. Thus, in modern Ukrainian society, despite the proclamation at the legislative level of the implementation of the principles of gender equality, there are stereotypes that form gender-role expectations, which, in turn, hinder its achievement.

\section{REFERENCES:}

1. Gender differences and the desire for self-actualization. URL: https: //zu.edu.ua/spf/pdf/Gender1/gn3.pdf.

2. Gender stereotypes and perceptions of gender discriminationofUkrainianusers.URL:https://ir.kneu.edu.ua/ bitstream/handle/2010/26817/MU_18_4_3.pdf? sequence $=1$ \&isAllowed $=\mathrm{y}$.

3. Gender stereotypes, or what society expects from men and women. URL: http://gender.at.ua/publ.

4. Gender stereotypes and public attitude to gender issues in Ukrainian society. URL: file: http://www.plsz. gov.ua/download/gender_stereotupu.pdf.

5. Goroshko O. Formation of the information society as a factor in the transformation of gender discourse. Bulletin of the International Slavic University: Ukrainian scientific-theoretical journal. Sociological sciences. Kharkiv, 2008. № 1. P. 6-11.

6. Karepova O. The influence of gender stereotypes on perception in modern society. URL: http://psyfactor. org/lybr74.htm.

7. Kravets T. Objectification of gender stereotypes in the Ukrainian mass media discourse. Linguistic and conceptual pictures of the world: Collection of scientific works. 2013. № 43/2. P. 252-257.

8. Magdyuk $L$. The influence of gender stereotypes on the representation of women and men in the labor market. Terrasoft. 2011. № 5. P. 7-10.

9. Peleshchyshyn A. Gender and age differences of language in Internet communication. Human. Computer. Communication : a collection of scientific papers. 2018. 